\title{
A provisional classification of algal-characterised rocky shore biotopes in the Azores
}

\author{
Ian Tittley' \& Ana I. Neto ${ }^{2}$ \\ ${ }^{1}$ Department of Botany, The Natural History Museum, London SW7 5BD. U.K. \\ Fax:+44 2075529. E-mail: I.Tittlev@nhm.ac.uk \\ ${ }^{2}$ Universidade dos Açores, 9500 Ponta Delgada, Açores, Portugal \\ Fax:+35I 29665.3455. E-mail: aneto@alf.ucic.pt
}

Key words: algae, Azores, biotope, community structure, rocky shores

\begin{abstract}
Recent studies of the rocky shores of the Azores archipelago have provided information on community structure allowing provisional identification of plant-characterised biotopes (habitats and their associated communities). Although the Azores share some littoral and sublittoral biotopes with the Atlantic coast of mainland Europe, shores in the archipelago mostly lack the functionally important 'leathery macrophyte' communities of fucoids and laminarians widespread in the North Atlantic. Intertidal biotopes are mainly turfs typical of warm-temperate and tropical regions, and characterised by articulated Corallinaceae or by non-coralline algae such as Cladophora spp., Gelidium spp., Pterocladiella capillacea, Stypocaulon scoparia, and Valonia utricularis. Subtidal algal biotopes are characterised by Dictyota spp., Halopteris flicina, Sphaerococcus coronopifolius and, most commonly, Zonaria toumefortii.
\end{abstract}

\section{Introduction}

Until the 1990s, ecological investigations that described marine algal community structure in the Azores were few (Schmidt, 1931; Pryor, 1967; Castro \& Viegas, 1983; Marques, 1984; Castro \& Viegas, 1987). The most thorough study was that of Schmidt (1931) who defined the algal associations (Table 1). In the past decade, detailed surveys have been undertaken throughout the archipelago and, as a result, there is now a more comprehensive body of information on community structure (Neto, 1992; Neto \& Tittley, 1996; Morton et al., 1998; Tittley et al., 1998; Neto et al., 2000). Tittley et al. (1998) provisionally identified some algal-characterised biotopes of the island of Flores following Hiscock (1995). The present paper provides, for the first time, a provisional classification of algal-characterised biotopes drawn from field studies on the islands of Flores, Faial and São Miguel.

A biotope is defined as "a seashore or sea-bed habitat (i.e. the environment's physical and chemical characteristics, and the particular conditions of wave exposure, salinity, tidal streams and other factors which contribute to the overall nature of the location) and its associated community of species, operating together' (Connor et al., 1997a, b). In this paper, Azorean littoral and sublittoral biotopes characterised by algae are defined provisionally following the methods of the Marine Nature Conservation Review (MNCR) (Connor et al., 1997a, b). The MNCR classification aims to be comprehensive, and includes biotopes for artificial, polluted or barren areas and is intended to complement other marine classifications (e.g. in France, Dauvin, 1995). This paper focuses on rocky shores (as opposed to sedimentary shores), the primary division of the biotope classification. Generally, rocky shores provide the stable substratum required for algal growth.

\section{Materials and methods}

Schmidt (1931) applied the phytosociological methodology of Braun-Blanquet used also by other workers to classify marine vegetation on continental European coasts [e.g. Den Hartog (1959) for the Netherlands]. There are similarities between the phytosociological 
Table I. Azores algal arrociations of Schmidt (1931) and biotope equivalents als defined in this paper

\begin{tabular}{|c|c|}
\hline Association & Biotope \\
\hline \multicolumn{2}{|l|}{ Open Litroral } \\
\hline Bangia-Cyanophylal & Cyanobacteria-Bamsia \\
\hline Lidhina pygnaed & Lichina premaed \\
\hline Polssiphonia & $?$ \\
\hline Nemalion-Grateloupin-Bryopsis-Cladophont & Soft algal turf complex \\
\hline Enteromorpha & Enteromorpha \\
\hline Fucus spiralis & Fucus spiralis \\
\hline Gelidium microdon & Geliditm microdon \\
\hline Lamencia obruser & Soft algal turf complex \\
\hline Haliptyon ringanum & Coralline algal turf complex \\
\hline Caulacanthus-Chondracanthus-Ceraniaceate & Soft algal turf complex \\
\hline Gelidim-Codmm adhaerens & Codium adhaerens \\
\hline Conallina elongata & Coralline algall turf \\
\hline Cystoseina & Cystoseire \\
\hline Osmundea pimnatifida & Soft aigal turf complex \\
\hline \multicolumn{2}{|l|}{ Shaded littoral } \\
\hline Gymmogongrus-Lomentaria-Rhodymenia & Shade turf \\
\hline Catenella & Shade turf-Catenella \\
\hline Griffithsia phyllamploora & $?$ \\
\hline Halipțlon squamatum & $?$ \\
\hline Crustose algae & Shade crustose spp. \\
\hline \multicolumn{2}{|l|}{ Sublittoral } \\
\hline Corallina officinalis & Corallina turf complex \\
\hline Asparagopsis & Asporragopsis turf \\
\hline Surgassum-Cladostephus-Nitophyllum-Ploceminm & $?$ \\
\hline Crustose algae & Crustose algae \\
\hline
\end{tabular}

and biotope methods in defining marine algal communities. Schmidt's (1931) sublittoral observations were limited as SCUBA diving had not been developed at that time and sublittoral areas were sampled by dredging, an inexact method of surveying the vegetation of such habitats. Although many of the transect and quadrat stuclies recorded in recent surveys have provided data that support Schmiclt's (1931) observations, the MNCR biotope classification was taken as a starting point for this paper.

The MNCR biotope classification is hierarchical and based on a matrix of environmental features including substratum type. wave exposure conditions. and shore level (Connor et al., 1997a. b). Within each of the major divisions of substratum. biotope complexes" (a broad feature often comprising several biotopes) were identified for each of the main shore zones (littoral, infralittoral, circalittoral) and four points on a scale of wave exposure conditions from very exposed to sheltered. Other biotope complexes (rock pools, overhangs, caves) were classified separately. For each biotope, a name is given together with a coded classification representing substratum type, wave exposure conditions and the characterising species. A description is provided also for each biolope, the characterising and other associated species are listed. For this provisional assessment of Azorean biotopes. we provide only a name.

The present study used both descriptive and quantitalive data cobtained from quadrats along transect lines) to define provisionally algal-characterised biotopes. Field studies weje undertaken at littoral and sublittoral levels (to $30 \mathrm{~m}$ depth) in a range of wave cxpostire conditions from sheltered to exposed. 


\section{Results}

As the focus of this paper is on algal biotopes. some animal-characterised biotopes have been omitted from the classification. Table I presents the 24 algal associations defined by Schmidt (1931) with. where possible, a modern biotope or biotope complex equivillent. Of the associations identified by Schmidt (1931), two were restricted to supralittoral levels, 12 occurred in the littoral in full light conditions, a further five occupied shaded littoral situations and five were recorded from sublittoral areas.

Tables $2 \mathrm{a}$, b present the biotope complexes in the Azores using the matrix structure of the MNCR biotope classification (cf. Table 5.2 in Connor et al., $1997 \mathrm{a}, \mathrm{b})$. At both littoral and sublittoral levels, these complexes in the Azores are similar irrespective of wave action. An important cavear is the definition of the scale of wave action in the Azores; there are probably no truly sheltered habitats in the archipelago comparable to those of sea lochs and inlets in Britain.

Tables $2 \mathrm{a}, \mathrm{b}$ also present actual biotopes within the complexes (cf. Table 5.5 'Littoral rock habitat matrix' in Connor et al. 1997a, b). On wave exposed shores at supralittoral levels, the principal biotopes are characterised by various yellow lichens; at supralittoral fringe levels, black lichens (Verrucaria spp.) and Cyanobacteria crusts characterise a set of biotopes. Littorinids [Melarhaphe neritoides Linnaeus (1758) and Littorina spp.] often form a distinct animal biotope at upper midlittoral levels overlapping at lower levels with patches of the marine lichen Lichina pygmaea (Lightfoot) C. Agardh which may also form a distinct biotope. A feature of most Azorean shores (from very wave exposed to more sheltered situations) is an eulittoral 'barnacle-limpet' biotope complex. This may be intemupted by green algal (Blidingia spp., Enteromorpha spp.) biotopes according to season, wave action, presence of pools and draining water. The crustose coralline alga Tenurea tortuosa (Esper) Me Lemoine also forms a biotope in the 'barnacle-limpet' complex. On less wave exposed, more sheltered shores, the biotopes are broadly similar. In spring, the Cyanobacteria biotope may contain noticeable amounts of the filamentous red alga Bangia atropurpurea (Roth) C.Agardh and Porphyra umbilicalis (Linnaeus) Kützing. The only fucoid in the Azores, Fucus spiralis Linnaeus, occurs patchily as small plants and locally defines a biotope.

On both wave exposed and more sheltered shores, lower littoral levels commonly support algal 'turfs'
A turf is a convenience term to describe compact, sometimes densely intertwined mats of algae (Neto \& Tittley, 1996). We have identified two broad types of turf biotope complex. those characterised by soft (mainly non-calcined) algae (e.g. Gelidium spp. Pterocladiclla capillacea (S.G.Gmelin) Santelices \& Hommersand, Stypocaulon scoparia (Linnaeus) Kützing, Cladophora spp., Valonia utricularis (Roth) C. Agardh], and those by calcified, articulated Corallinaceae (e.g. Corallina spp., Jania spp., Haliptylon spp.). Coralline turfs are a distinct feature of many rocky shores in the Azores, comprise several biotopes and extend to deep sublittoral levels. The soft algal turf is often species rich and comprises a complex of biotopes. The prostrate Codium adhaerens C. Agardh characterises a distinct biotope at low-water level on many shores. Crustose coralline algae are the dominant life forms and form a biotope on strongly wave washed rocky shores in the surge zone at shallow sublittoral levels. At sublittoral fringe levels, prolific growths of Asparagopsis amata Harvey often define a distinct summer biotope.

Occasionally, large brown algae may form biotopes at lower littoral or sublittoral levels. Morton et al. (1998) reported a carpet of Cystoseira tamariscifolia (Hudson) Papenfuss on the island of Santa Maria.

Intertidal areas are often modified to form rock pools, overhangs and caves and distinct algal communities are associated with these. Shaded habitat biotopes may have Lomentaria articulata (Hudson) Lyngbye or Catenella caespitosa (Withering) L. Irvine as the dominant species, or the crustose red alga Hildenbrandia sp. Pool biotopes are often characterised by the large brown algae Cystoseira spp. and Sargassum spp.

At subtidal levels, foliose algae are more prominent; the green alga Ulva rigida C. Agardh, and the brown alga Padina pavonica (Linnaeus) Thivy. are locally, seasonally, predominant at São Vicente on the island of São Miguel. Another brown alga, Zonaria tournefortii (Lamouroux) Montagne, forms extensive stands throughout the archipelago often to considerable depths. The red algae Sphaerococcus coronopifolius Stackhouse and Plocumium cartilaginem (Linnaeus) P.S. Dixon characterise biotopes in deep water. On the island of Faial, the Corcllina turf extended to $30 \mathrm{~m}$ depth. The Formigas islets are unique in the Azores in the occurrence there of the leathery macrophyte kelp, Laminaria ochroleuca De La Pylaie; this single recorded example of a kelp-characterised 
Table 2a. Habiat matrix in tho Azores. Biotope complexes and (indented) species characterising probable biotopes

\begin{tabular}{|c|c|c|}
\hline & Very exposed & Exposed \\
\hline \multicolumn{3}{|l|}{ Supra- } \\
\hline littoral & Yellow \& grey lichens & Yellow \& grey lichens \\
\hline \multicolumn{3}{|l|}{ Upper } \\
\hline Litcoral Fringe & Cyanobacteria-Vemancara & Cyanobacteria-Vemataia \\
\hline \multicolumn{3}{|l|}{ Lower } \\
\hline Litural Fringe & $\begin{array}{l}\text { Littorinids } \\
\text { Lichina pygnatea }\end{array}$ & $\begin{array}{l}\text { Litioninids } \\
\text { Lichinu prgmerea }\end{array}$ \\
\hline \multicolumn{3}{|l|}{ Uррет } \\
\hline Eulittoral & $\begin{array}{l}\text { Barnacles-limpets } \\
\text { Encromorpha spp. }\end{array}$ & $\begin{array}{l}\text { Barnacles-limpets } \\
\text { Enteromorpha spp. }\end{array}$ \\
\hline \multirow[t]{2}{*}{$\begin{array}{l}\text { Mid } \\
\text { Eulittoral }\end{array}$} & Bamacles-limpets & $\begin{array}{l}\text { Fucus spiralis } \\
\text { Gelidium microdon }\end{array}$ \\
\hline & Tentwe a tornosa & Tenarea tormosa \\
\hline Lower & Soft algal turf & Soft algal turf \\
\hline Eulittoral & $\begin{array}{l}\text { Gelidium latifolium } \\
\text { Cladophora prolifera } \\
\text { Chondracamthus acirularis }\end{array}$ & $\begin{array}{l}\text { Gelidium Latifolimm } \\
\text { Osmundea pimatifida } \\
\text { Rhodymenia pseudopalmata } \\
\text { Codium adhaerens }\end{array}$ \\
\hline Rockpool & $\begin{array}{l}\text { Rockpool } \\
\text { Corallina spp. } \\
\text { Sargassim spp. } \\
\text { Crstoseira spp. }\end{array}$ & $\begin{array}{l}\text { Rockpool } \\
\text { Coralina spp. } \\
\text { Sargassim spp. } \\
\text { Cistoseira spp. }\end{array}$ \\
\hline \multirow{2}{*}{$\begin{array}{l}\text { Sublittoral } \\
\text { Fringe }\end{array}$} & Coralline turf & Coralline turf \\
\hline & Crustose Corallinaccae & $\begin{array}{l}\text { Crustose Corallinaceae } \\
\text { Asparagopsis amata }\end{array}$ \\
\hline \multirow[t]{3}{*}{ Sublittoral } & & $\begin{array}{l}\text { Soft algal turf } \\
\text { Srypocalon scoparimm }\end{array}$ \\
\hline & Foliose algae & Foliose algae \\
\hline & $\begin{array}{l}\text { What rigida } \\
\text { Zomaria tom nefortii } \\
\text { Dictrota spp. }\end{array}$ & $\begin{array}{l}\text { Uha rigida } \\
\text { Zonaria toumefortii } \\
\text { Dictrota spp. }\end{array}$ \\
\hline Deep & Red algae & Red algale \\
\hline Sublittoral & $\begin{array}{l}\text { Splaerococcus coronopifolias } \\
\text { Plocamium cartilaginum } \\
\text { Kelp stand } \\
\text { Laminaria ochroleuca }\end{array}$ & $\begin{array}{l}\text { Sphaerocoscus coromopifolius } \\
\text { Plocumium cartilagineam }\end{array}$ \\
\hline
\end{tabular}


Table 2h. Habitat matrix in the Azores (biotope complexes and (indented) keystone species chatraterising probable biotopes)

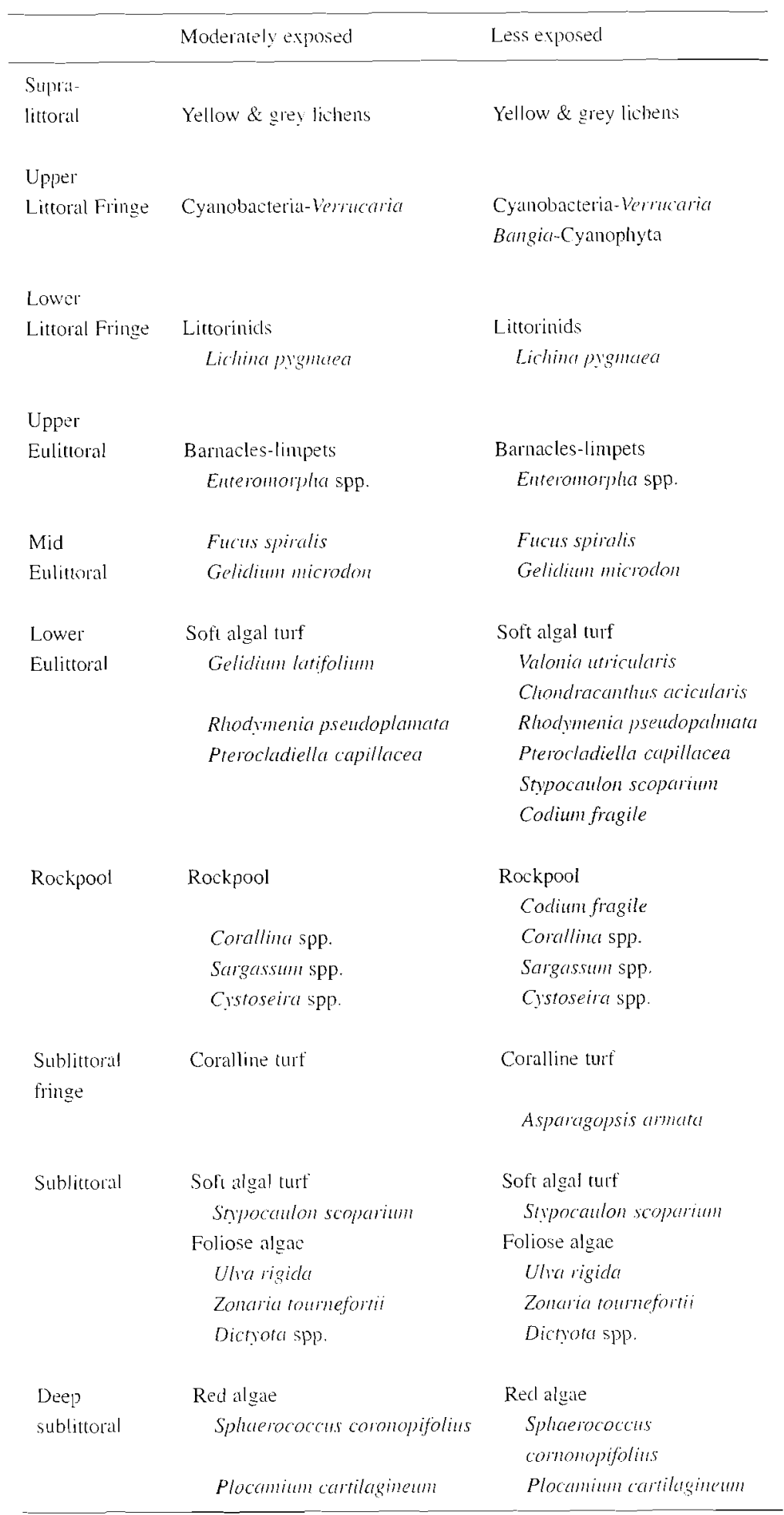


biotope occurs only in deep waters $(30-40 \mathrm{~m}$ and below).

\section{Discussion}

A major distinction between the algal-characterised biotopes of the Azores and those of the northern North Atlantic in both Europe and America is the near absence of the leathery macrophyte communities of fucoids and Jaminarians. Where algae predominate in the Azores. they are often turf forming. Algal turf biotopes also occur in the northern North Atlantic Ocean. For example. an Osmundea pinnatifida (Hudson) Stackhouse and Gelidium pusillum (Stackhouse) Le Jolis turf occurs on moderately exposed mid-littoral rock in Britain where the fucoid canopy is reduced or absent (Connor et al., 1997a, b); both species are turf-forming constituents in the Azores but such turfs in Britain are less common and less species rich. The non-coralline algal turf biotope is typical of other Macronesian islands and also tropical West Africa where Lawson \& John (1987) described a red algal turf as a principal feature of intertidal shores. A biotope defined by 'Corallina officinalis on very exposed eulittoral rock' (Connor et al., 1997a, b) occurs widely in the northern North Atlantic and also in the Azores, usually as pure stands of $C$. officinalis Linnaeus in its typical form. A second Corallina turf biotope also occurs in the Azores and comprises a compact and tightly entangled species-rich mat in which Corcllina is less recognisable and mixed with other articulated Corallinaceae, this biotope closely resembles Corallina turfs described from the Canary Islands (Lawson \& Norton. 1971), West Africa (Lawson \& John, 1977), Mexico (Stewart, 1989) and Brazil (Oliveira \& Mayral. 1976). The predominance at sublittoral levels of the foliose Zonaria tommefortii biotope contrasts with the predominance of leathery macrophyte kelp biotope complexes of the North Allantic but is a feature of Madeira (Levring, 1974) and the Mediterranean (Garcia \& Carrascosa. 1987. Drago et al., 1997).

Although sea urchins graze areas clear of noncalcified algae to reveal a biotope characterised by crustose Corallinaceae, such cleared areas are restricted in extent in the Azores and contrast with localities on Madeira where this "urchin barren" biotope is widespread and extends into deep waters (pers. obs). In the Azores. the littoral limpets have been removed by human predation (and thus the biotope destroyed) allowing algal assemblages to develop in areas that would otherwise lack such growth (Martins et al. 1987).

\section{Conclusions}

The improving body of knowledge of algal community structure and its dynamics has encouraged the application of the MNCR biotope method to marine community classification in the Azores. Although the biotope method was developed in Britain as a tool to aid management and conservation of marine habitats, its general principles can be applied to other geographical areas. In the present study, the method has helped identify differences in algal community structure between Britain and the Azores. It will also provide a useful monitoring tool to assess change in marine communities in the Azores whether natural or anthropogenic.

\section{References}

Castro. M. L. \& M. C. Viegas, 1983. Estudo dos povamentos de algas folófilas da ilha de S. Miguel (Açores). I - Resultados preliminaires sobre facies de Corallina elongata Ellis \& Solander. Arquipélago 4: 7-30.

Castro. M. L. \& M. C. Viegas. 1987. Contribuição para o estudo da zona intertidal (substrato rochoso) da ilha de São MiguclAçores. Fácies de Corallina elongata Ellis \& Solander. Resultados preliminares. Cuad. Marisq. 11:59-69.

Connor, D.. D. P. Brazier. T. O. Hill \& K. O. Northen 1997a. Marine Nature Conservation Review: marine biolope slassification for Britain and Ireland. Volume 1. Littoral biotopes. Version 97.06. JNCC Report. No. 229: 362 pp

Connor, D.. M. J. Dalkin. T. O. Hill. R. H. F. Holt \& W. G. Sanderson, 1997b. Marine Nature Conservation Review: marine biotope classification for Britain and Ireland. Volume 2. Sublittoral biotopes. Version 97.06. JNCC Report, No. 230: $4+8$ $\mathrm{pp}$.

Dauvin. J.-C., 1995. The development of the marine ZNIEFF (Zones Naturelles d’Intérêt Ecologique. Faunistique er Floristique) in France. In Hiscock. K. (ed.). Classification of Benthic Marine Biotopes of the North Fast Atlantic. Proceedings of a Biomar-Life workshop held in Cambridge 16-18 Novenber 1994. Joint Nature Conservation Conmittee. Peterborough: 47-53.

Den Hartog. C.. 1959. The epilithic marine algal communities of the Netherlands coast. Wentia 1: 1-2+1.

Drigo. D. A. M. Mannino \& S. Sortino. 1997. La vegerazione sommersil dei mari siciliani Lineanmenti iconografici. LEPOS. Palemo: $117 \mathrm{pp}$.

Garcia Carrascosa, A. M. 1987. Fl bentos de los alrededores de las Islas Columbretes. Elementos para a sua carlografia bionómicil. ln Alonso M. L. A.. J. L. Carrere \& A. M. G. Conracosal (eds). Islas Columbretes. Contribución al Estudio de su Medio Nittural. Genelalitat Valencianal. Valencial: 477-507.

Hiscock. K.. 1995. Classification of benthit martine biotopes of the not ealst Allantic. Procedings of B Biomall-Lite workshop held 
in Cambridge 16-18 November 1994. Joint Nature Conservation Committee, Peterborough: $105 \mathrm{pp}$.

Lawson. G. W. \& D. M. John, 1977. The marine flora of the Cape Blanc peninsula, its distribution and affinities. Bot. J. lian. Soc. 75: 99-118.

Lilwson, G. W. \& D. M. John. 1987. The marine algae and coustal environment of tropical West Africa (Second Edition). Beilu. Nova Hedwigia 83: i-vi $+1-415$.

Lawson, G. W. \& T. A. Norton, 1971. Sone observations on littoral and sublittoral zonation at Tenerife. Canary Isles. Bot. Mar. 14: $116-120$.

Levring, T., 1974. The marine algae of the archipelago of Madeira. Bol. Mus. Mun. Funclal 28: 1-111.

Marques, V. M., 1984. Effects of Arbacia lixula (L.) (Echinoidea) on the algal communities of São Miguel and Graciosa Islands (Azores Archipelago, Portugal). Arq. Mus Boe.. $2^{a}$ sér. B, 13: $103-108$.

Martins, H., R. S. Santos \& S. J. Hawkins. 1987. Exploitation of limpets (Patella spp.) in the Azores with a preliminary analysis of the stocks. Report to ICES Selfish Committee (C. M. 1987/S3): $14 \mathrm{pp}$.

Morton, B.. J. C. Britton \& A. M. De Frias Martins, 1998. Coastal ecology of the Azores. Sociedade Afonso Chaves, Ponta Delgada. viii $+249 \mathrm{pp}$
Neto. A. I., 1992. Contribution to the taxonomy and ecology of the Azorean benthic marine algae. Biol. J. timn. Soc, 46: 163-176.

Neto. A. I. \& I. Tittley. 1996. Strucute and zonation of algal turf communities on the Azores: a numerical approach. Bol. Mus. Mun. Funchal Suppl. No. 4: 487-504.

Neto. A. L.. I.Titrley. A. Levi \& W. F. Farnhant. 2000. Stucture and zonation of algal communities in the bay of São Vicente (São Miguel, Azores). Arquipélago Suppl. 2 (Part A): 63-69.

Oliveira Filho, E. C. De \& E. M. Mayral, 1976. Seasonal distribution of intertidal organisms at Ubatuba. São Paulo (Brazil). Rev. Bras. Biol. 36: 305-316.

Plyor, J.. 1967. Intertidal marine algae of São Jorge. In Chelsea College Azores Expedition July - October 1965. Final Report, London: $17-30$.

Schmidt, O. C.. 1931. Die marine Vegetalion der Azoren in ihren Grundziigen dargestellt. Bibl. Bot. 24: 1-116.

Stewart. J. G.. 1989. Establishment. persistence and dominance of Corallina (Rhodophyta) in algal turf. J. Phycol. 25: 436-446.

Tittley, I.. A. I. Neto \& W. F. Farnham, 1998. Marine algae of the island of Flores, Azores: ecology and floristics. Bol. Mus. Mun. Funchal Suppl No. 5: 463-479. 